\title{
Beyond Budgeting in Statoil
}

\author{
Bjarte Bogsnes \\ Statoil, Forusbeen 50, N-4035 Stavanger, Norway \\ bjboastatoil.com
}

\begin{abstract}
It is both scary and amazing to observe how little management practices have developed over the last fifty years, a period where we have seen groundbreaking innovation in most other parts of business and technology. My sons who now are finalizing their business studies could easily have used many of my own textbooks from thirty years ago, especially those covering budgeting, planning and performance management. Most business schools still teach, and most companies still practice a "command-and control" approach born in a time when the pace and predictability of business environments were radically different, and when the expression "knowledge organisation" did not exist.

Statoil is Scandinavia's largest company. One of it's values reads "Challenge accepted truth, and enter unfamiliar territory". Bjarte Bogsnes will share Statoil's long journey, which by no means is over, towards a new coherent management model which "takes reality seriously" both from a business and people perspective. He will advocate the need for joining forces with HR on this journey, because management processes must be fully aligned with leadership principles and practices. The two communicating opposing messages is a recipe for confused and disillusioned employees. Bogsnes will also argue that organisations will not succeed with their lean and agile efforts on development projects unless lean and agile also becomes the way the organisation, and not just it's projects, is run.
\end{abstract}

